\title{
Transmission of Prices Between Individual Links in the Production and Distribution Channel of Cereals and Cereal Products of Primary and Secondary Processing in Poland in the years 2004-2018
}

\author{
Anna OLSZAŃSKA ${ }^{1, *}$, Martin KRÁL ${ }^{2}$ and Magdalena LUBOINSKA ${ }^{1}$ \\ 1 Wroclaw University of Economics and Business, Wrocław, Poland; anna.olszanska@ue.wroc.pl; \\ magdalena.luboinska@ue.wroc.pl \\ 2 University of Hradec Kralove, Hradec Kralove, Czech Republic; martin.kral.2@uhk.cz \\ * Correspondence: anna.olszanska@ue.wroc.pl
}

\begin{abstract}
The study analyzed data on an exemplary primary wheat processing product - Poznanska flour and then a product of secondary processing (plain mixed bread). The collected data refer to the years 2004-2019. The differences between the prices of cereal production and prices as well as the primary processing level and the prices of the secondary processing product are systematically increasing. At the first two levels, prices fluctuated quite significantly. The producers and the sellers of bread, during periods of significant decreases in cereal procurement price and the producer's price for flour, usually kept their prices at a similar level, while periods of rising prices for cereals and flour were used for significant price increases. Bread producers had a dominant position at individual production stages in the analyzed years. Their share in the final price was always the largest and most stable, and the price growth achieved by them was the highest. The strongest relationships were found between the average procurement prices of wheat and the selling prices of flour producers.
\end{abstract}

Keywords: price transmission; wheat procurement price; flour producers' prices; producers' and retail bread prices

JEL Classification: P22; P42; Q13

\section{Introduction}

In most food industries, the purchase price of raw material constitutes the main cost. In this context, one can follow the price formation process from the supply side of the raw material and the finished product that goes to the market. In a well-functioning market, it can be assumed that the prices of processed products will be correlated with the purchase price of the basic raw material. Finished product prices are also influenced by many factors on the demand side. The price of the raw material and the product at various stages of its production is, therefore, the result of many elements and factors appearing on the market in each place and time. The final price of the product is very important as it determines the competitiveness of this product on the market. An attractive final price, especially for necessities, i.e. food, provides a competitive advantage during trade exchange with foreign partners. The importance of price in trade in products from the food and agricultural industries is discussed in detail in the publications by i.e. (Firlej et al. 2017; Kowalska et al. 2017; Kowalska et al. 2019).

The study analyses the data on an exemplary primary wheat processing product - Poznanska flour and then a product of secondary processing (plain mixed bread). The price margins of individual links (cereal producers, millers, bakers and traders) accommodate the volume of production and transaction costs, the profits achieved as well as the inefficiency of the market system [4]. The ability to shape sales prices of the products and the implementation of short- and long-term marketing strategies, including pricing, depends on the position of individual links in the production and distribution channel. 
The purpose of the study is to analyze and evaluate price changes between individual links in the production and distribution channel of primary raw material (wheat), pre-processed product - wheat flour and secondary processing product - plain mixed bread.

\section{Methodology}

The data on the investigated products were taken from the studies of the Institute of Agricultural and Food Economics - PIB (Agricultural Market. Analyses, Trends, Assessment and Cereal Market (Status and Perspectives) as well as Agricultural Statistical Yearbooks published by the Central Statistical Office. The collection of data was conducted from the beginning of 2004 to August 2019. All the data used come from the reports prepared for the needs of the Central Statistical Office. Due to the changing level of inflation, the proportions between prices were mainly expressed in the form of price relations. The relationships were examined using basic methods of statistical analysis of data, including calculations of correlation coefficients between prices on individual links of the marketing chain.

\section{Results and Discussion}

In the analyzed years, domestic consumption of cereals and cereal products fluctuated significantly. The size of grain milling varied from 3200 thousand tons in 2008 to 3909 thousand tons in 2006 (Fig.1). After relatively significant fluctuations in the first five years of the period under review, a gradual and relatively steady increasing tendency in the volume of cereal milling for consumption was observed in subsequent years. In 2018, it reached the level of 3835 thousand tons. The trends in the production of wheat flour were similar. Its share in the total flour production was relatively constant during this period. The minimum volume was recorded in 2008 and it amounted to 2093 thousand tons and the maximum in 2006 when it reached 2543 thousand tons. The coefficient of variation for grain milling volume was $5.61 \%$ and in the case of wheat flour production $-5.41 \%$. Slightly different trends occurred in the production of fresh baked goods. In this case, the changes were smaller $(3.74 \%)$ and they occurred regardless of the fluctuations of the two previously analyzed values. The minimum bread production volume was recorded in 2018 (1519 thousand tons) and the maximum in 2013 - 1689 thousand tons.

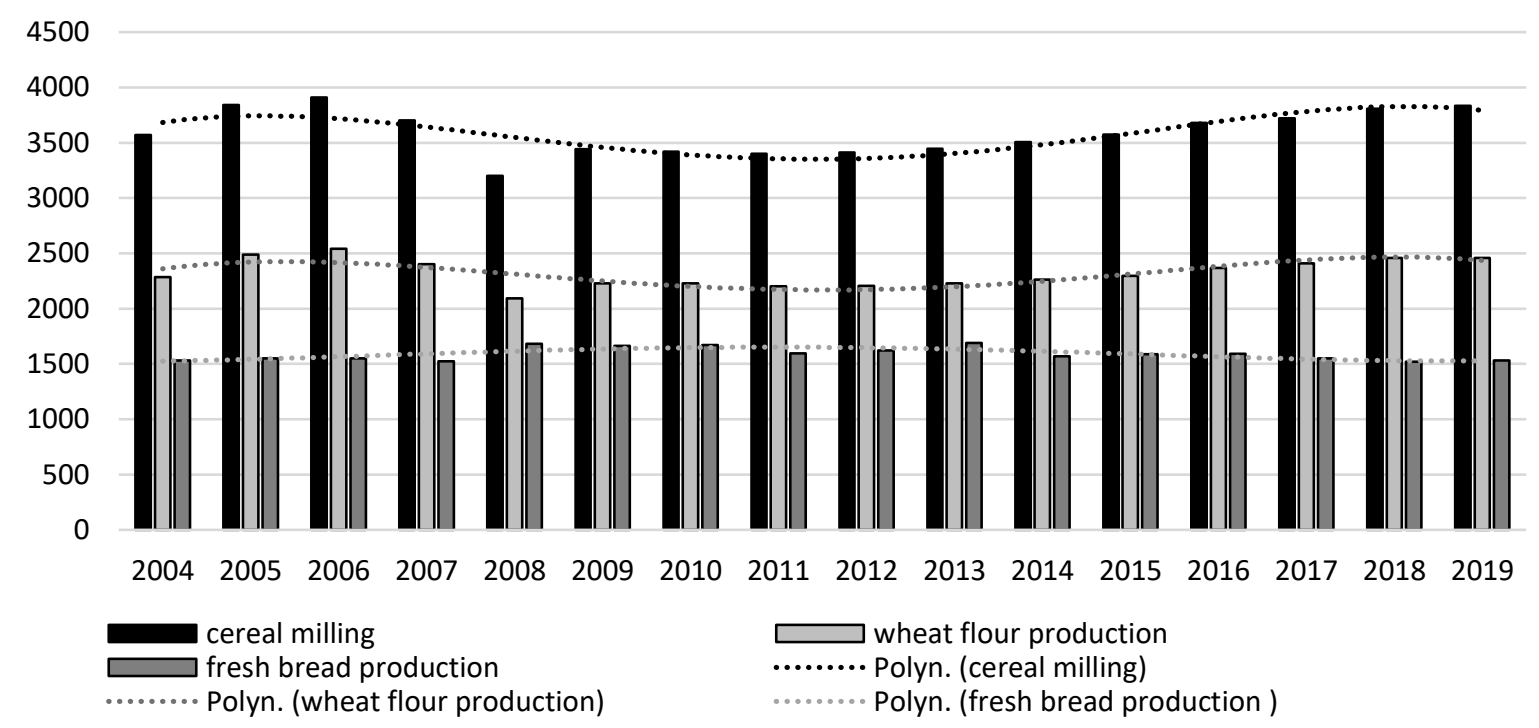

Figure 1. Cereal milling, wheat flour production and fresh bread production in Poland in 2004-2018 (thousand tons).

Demand for cereal processing products in Poland gradually decreased (Fig.2). Their total consumption in flour equivalent decreased at an average rate of about $1.3 \mathrm{~kg} /$ person/year, from $119 \mathrm{~kg}$ 
in 2004 and 2005 to $100.6 \mathrm{~kg}$ in the last year of the analysis. This means a decrease of about $15 \mathrm{pp}$. The average consumption of bread dropped much faster, at a rate of about $2.4 \mathrm{~kg} /$ person/year. In the analyzed period, this consumption decreased by as much as $47 \mathrm{pp}$. In both cases, very high trend line fits were obtained, which indicates that also in the coming years these values shall be largely predictable. This is a serious challenge for the baking industry. How, in the case of such decreasing demand, to stay in the market and what marketing strategy to use to get relevant revenues from the sales of products.

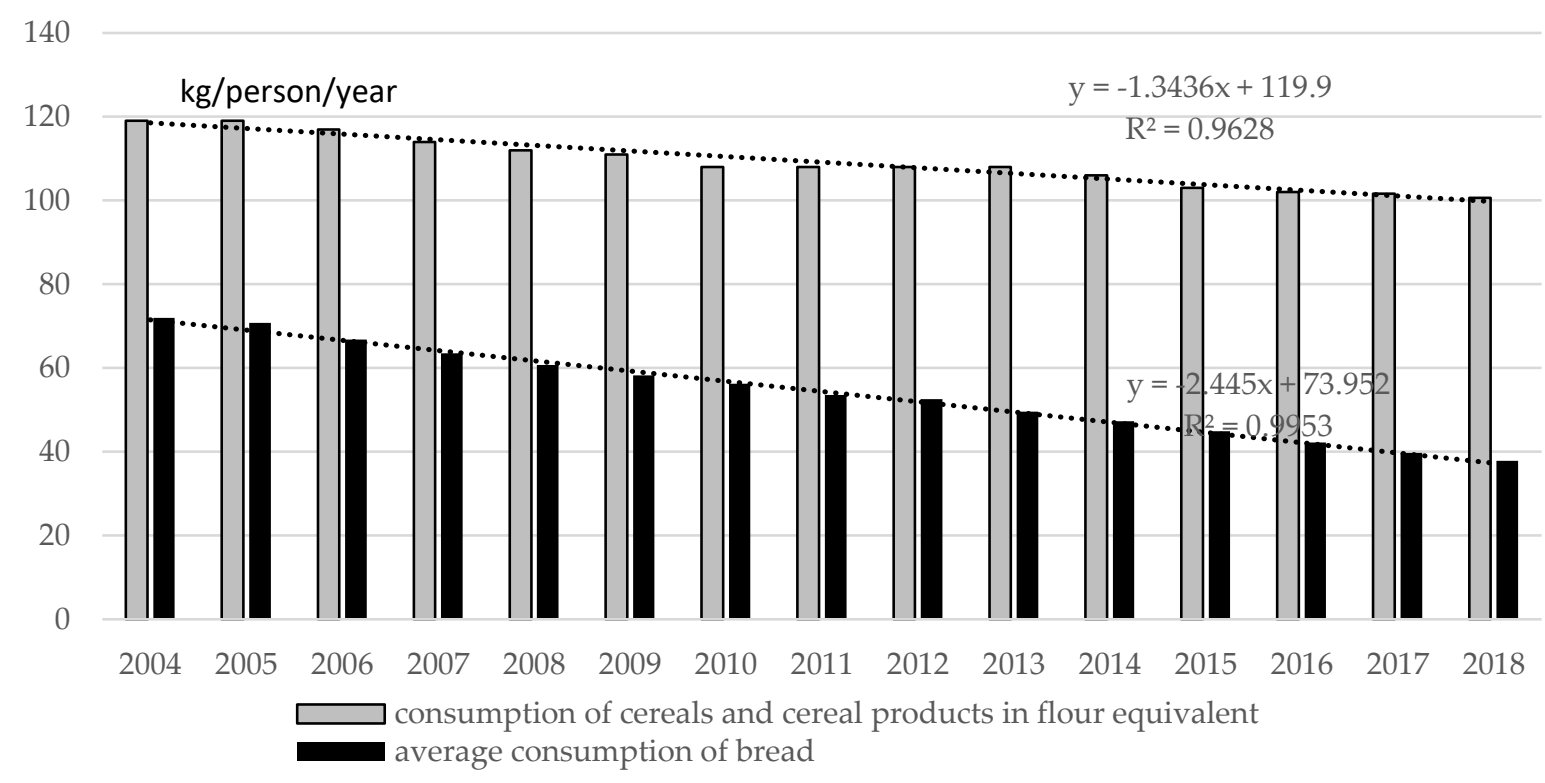

Figure 2. Average annual consumption of cereals and cereal products in flour equivalent as well as average consumption of bread in Poland in 2004-2018 (kg/person/year).

The next drawing (Fig.3) presents how the average prices changed at individual stages related to the production of plain mixed bread, starting from wheat procurement prices, through the prices of flour producers, the prices of bread producers, ending with retail prices of bread.

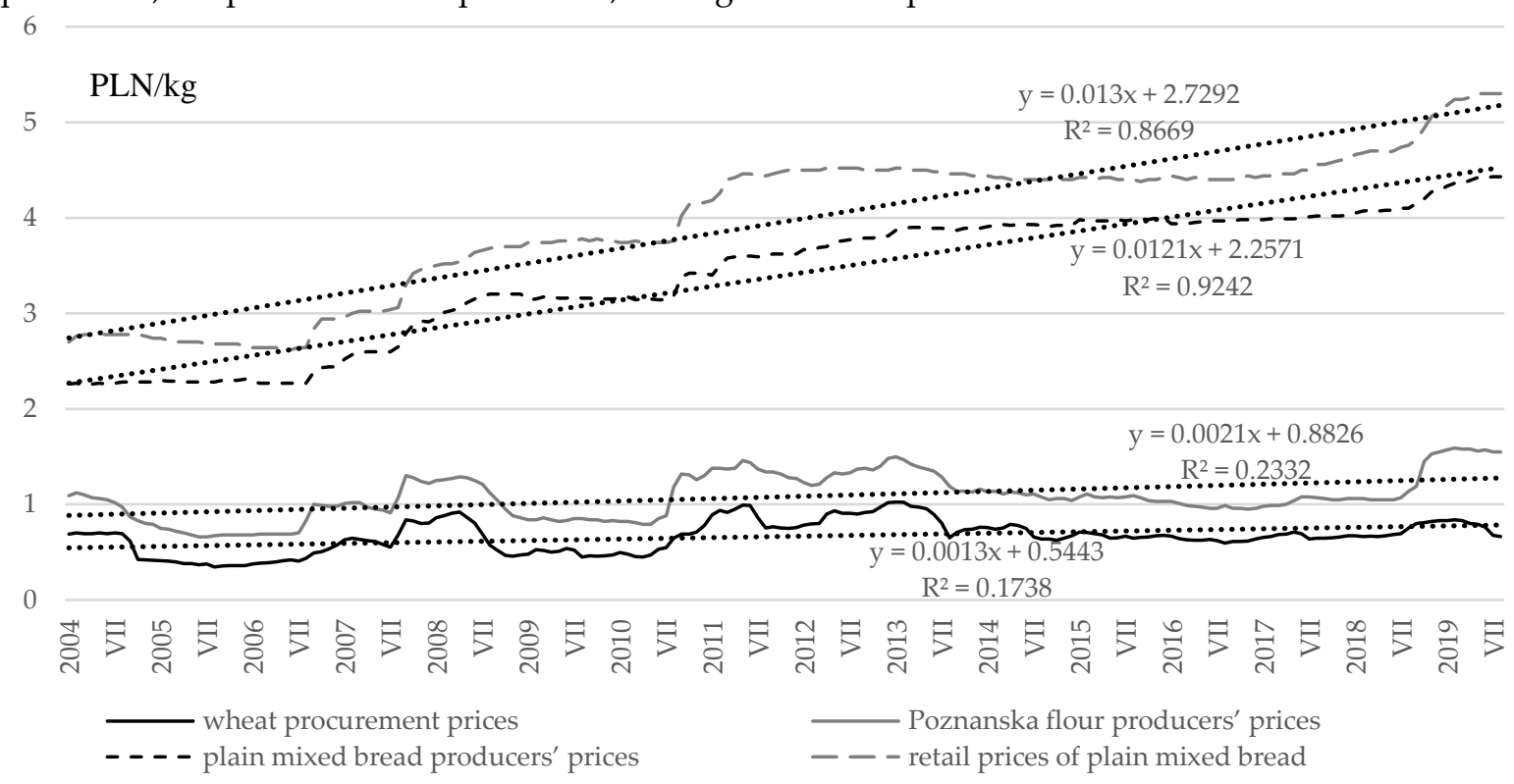

Figure 3. Average wheat procurement prices, flour producers' prices, bread producers' prices and retail prices of plain mixed bread in Poland in 2004-2019 (PLN/kg).

Even preliminary analyses show significant differences in the average price formation in the first two links of the marketing chain of bread production, covering wheat production and flour 
production, compared to the prices of bread producers' and the retail prices of bread. First, it is visible that the differences between the prices of cereal production together with the prices of the primary processing level and the prices of the secondary processing product tend to increase rather systematically.

Procurement prices of wheat fluctuated to the greatest extent over the period considered (coefficient of variation: $25.17 \%$ ). These prices changed quite significantly around the marked trend line with a minimal growth tendency. The average prices of flour producers were less variable $(21.95 \%)$. Trend line analyses indicate that these values have gradually increased over the years, to a greater extent than in the case of the wheat procurement prices. It should also be noted that in both cases the level of trend line fit was very low. The data initially indicate that these two links were strongly interrelated.

The average prices of bread producers also fluctuated significantly $(20.19 \%)$. However, they grew at a much faster rate compared to the previously analyzed prices. The retail prices of mixed bread increased even faster. The level of variation for these prices was the lowest and amounted to $19.3 \%$. The level of trend line fit was high in both cases. In both links, price fluctuations were not as sharp as in the case of cereal producers and milling industry. They were more extended in time and the given direction of price changes continued for a longer time.

These conclusions can be confirmed by the analysis of the dynamics of changes in the examined prices. The analysis comprised the calculation of dynamics with a fixed basis, for which January 2004 was adopted (Fig. 4). The procurement prices of wheat in numerous months were lower than those of January 2004. In September 2005 they reached the minimum level of approximately $52 \%$ of the average January 2004 price. Prices lower than the initial price were kept for three marketing years. In the 2008/2009 marketing year, they were more favorable in several months, but the next two made another period of low prices on this market. In subsequent marketing years until the 2018 harvest, prices fluctuated, but usually at a level like those from the beginning of 2004. Sales prices of the analyzed milling product changed in a similar rhythm, while in periods of low prices on the cereal market, the dynamics of flour sales prices were usually slightly more favorable. At a time when wheat procurement prices grew to a greater extent, the dynamics of the milling product sales price was slightly lower. After a long period of stabilization of wheat procurement prices and flour producers' prices, a significant change in the milling industry took place after the 2018 harvest. Flour selling prices increased in the following months to a much greater extent than wheat procurement prices and the market reacted only slightly to the rapid reduction in cereal prices in 2019.

The prices of bread producers' and the retail prices of this product were structured in a quite different manner. The average prices at these stages were quite stable until the 2006 harvest, and it was a period of a significant drop in prices in the first two links. Until August 2008, these prices used to rise steadily. In the final months, price increases in these links compared to January 2004 reached a similar level. When cereal and flour prices reached very low levels again (harvest season 2011), prices at these two successive levels stabilized again. Increases in the prices of cereals and flour in subsequent years were associated with further growth in prices at the bread production stage. Another long period of relative price stabilization at the stage of wheat procurement and flour production was again associated with price stabilization on the bread retail market and only a slight reduction in margins at the production stage. Such a strategy of conducting price policy in the bakery sector and in the retail trade of plain mixed bread led to the situation in July 2019 when the average purchase prices of wheat amounted to $98.4 \%$ of prices from January 2004, the selling prices of Poznanska wheat flour were at the level of $142.2 \%$ and selling prices of plain mixed bread and its retail prices $-196.3 \%$ of the prices from the beginning of 2004 .

Observing these data, it can be said that millers, at least until the harvest in 2008, responded to changes in the purchase prices of wheat by increasing and decreasing the selling prices of their product. Producers and traders of bread also closely monitored price changes at earlier stages of production of the raw material for their production, but they reacted in an entirely different way. In the periods of the price fall observed at the earlier stages, they stabilized their prices, and at the time of rising prices at earlier stages, they responded by a rapid increase in the prices of their products. As a result, despite growing inflation, farmers obtained for their product, in some periods, prices lower 
than at the beginning of 2004. A similar situation remained also until the 2018 harvest at the milling level, while the average selling and retail prices of plain mixed bread increased in the analyzed fifteen years almost twofold.

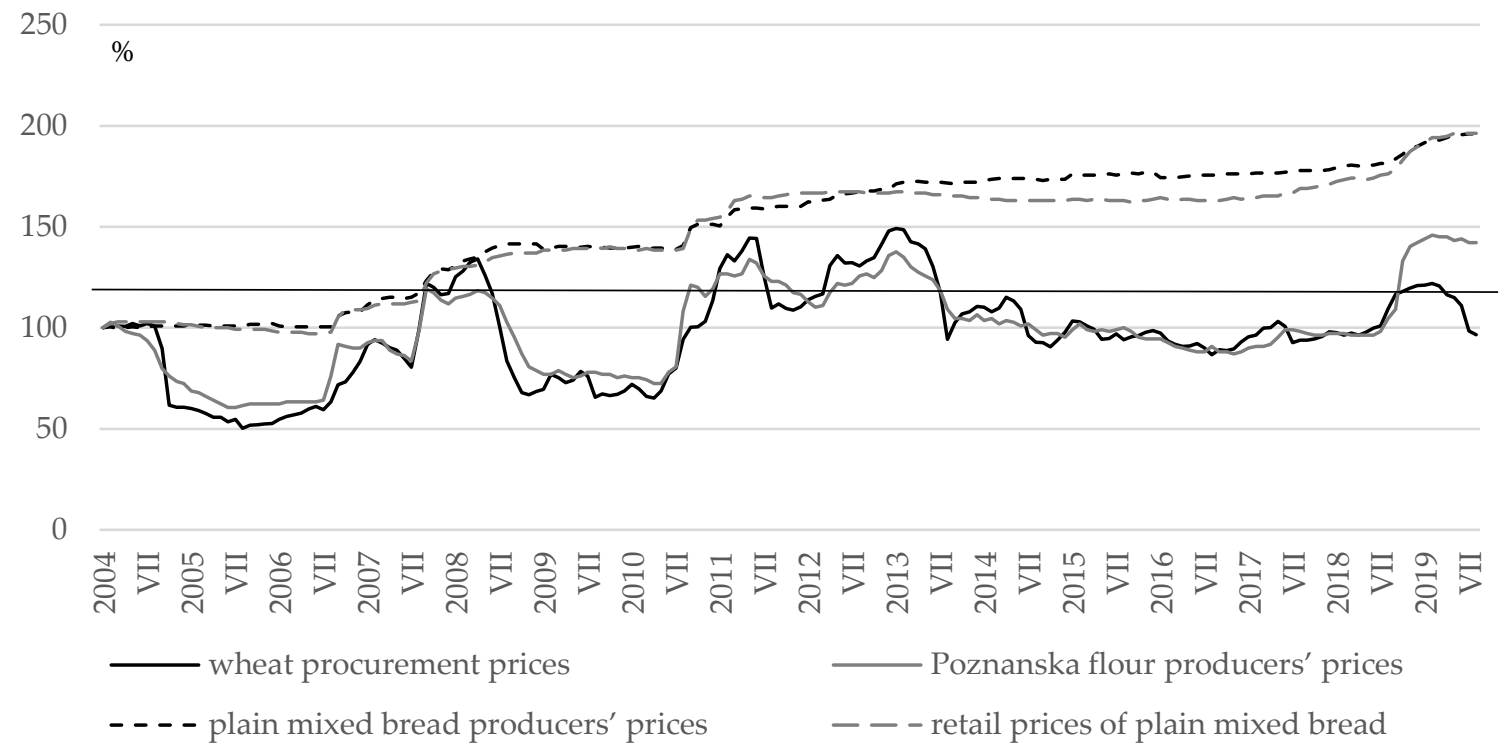

Figure 4. Dynamics of average wheat procurement prices, the producers' prices of Poznanska flour as well as the producers' and the retail prices of plain mixed bread in Poland in 2004-2019 (January 2004 $=100 \%$ ).

Further observations on the functioning of these markets are possible thanks to the analysis of figure 5 and 6 that present the shares of individual links in the retail price of plain mixed bread.

80

60

40

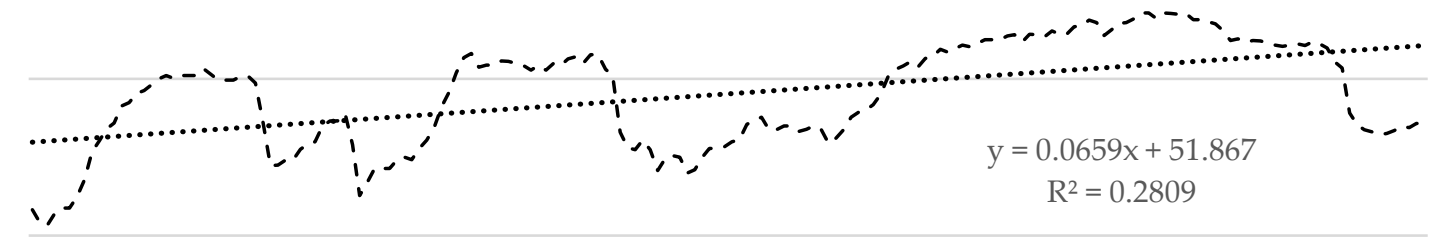

20
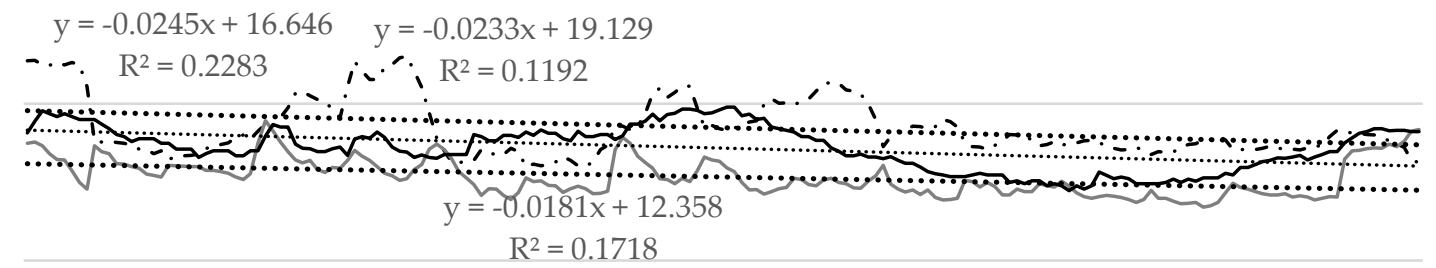

0

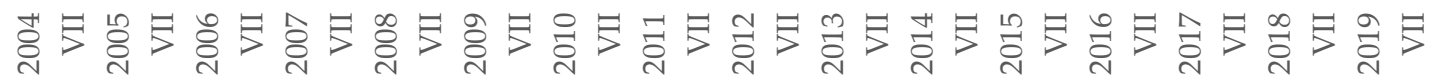

$$
\begin{aligned}
& \text {-. - - share of wheat procurement price in the retail price of bread } \\
& \text { - share of flour producer's margin in the retail price } \\
& \text { - - - share of bread producer's margin in the retail price }
\end{aligned}
$$

Figure 5. Shares of average wheat procurement prices, the producers' prices of Poznanska flour and the producer's price in the retail prices of plain mixed bread in Poland in 2004-2019 (\%).

The largest share in the retail price of plain mixed bread in the whole analyzed period had the bakery margin, the share of which ranged from $41.37 \%$ (such share occurred at the beginning of the analyzed period) to $68.41 \%$ (which was recorded in 2016). Shares below $50 \%$ were registered in the first three quarters of 2004 and the last quarter of 2007 and 2008. These were the periods of rising 
procurement prices for wheat. In the subsequent period, when these prices used to rise (2011 harvest), the margin was about $50 \%$. In the following similar periods, no impact of the growth of wheat price on the bakery margin level was noted. Margins above 60\% occurred in the 2005/2006 marketing year, from the fourth quarter of 2008 to harvest in 2010, and from harvest in 2013 to the end of the third quarter of 2018. In total, in 98 out of the 188 months analyzed (52.8\%), bakery margins were higher than $60 \%$. Margins below $50 \%$ occurred in 23 months (12.2\%). The presented data indicate that in $88 \%$ of the surveyed months the share of bakery margin in the price of plain mixed bread was at least $50 \%$. The variation of these shares was the lowest among the analyzed ones and amounted to $11.6 \%$. Hence, it can be concluded that the bakery margins were the highest and the most stable. The margins at the previous three stages were lower.

Procurement prices of wheat had the second-largest share. Their share in the retail price of the finished product ranged from 11.94 (after the harvest in 2009) to 26.03\% (April 2008). In $23.4 \%$ of the analyzed months, wheat procurement prices had over $20 \%$ share in the price of bread, while in $40 \%$ of the months, those shares were lower than $15 \%$. The variation of the share of wheat procurement prices in the retail price of bread was $21.7 \%$. The margin of Poznanska wheat flour producers and the trade margins had comparable shares at the price of the analyzed final product. In the first case, the share of these margins ranged from 6.8 to $17.82 \%$ and the variation of these values was minimal although the highest among the three margins discussed in this part (22.3\%). The shares of the trade margin in the retail price of bread ranged from 8.9 to $19.6 \%$ and the variation in the values of these margins was $19.5 \%$.

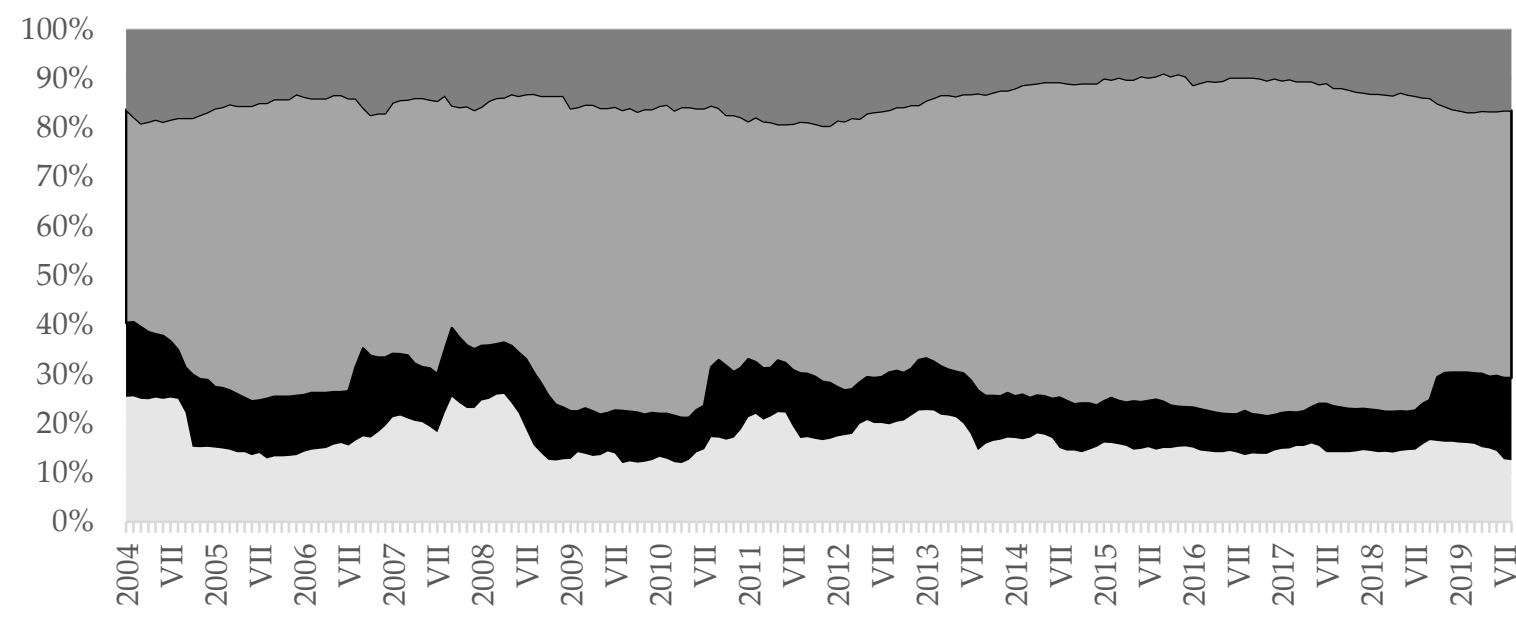

share of trade margin in the retail price of bread

$\square$ share of bread producer's margin in the retail price

- share of flour producer's margin in the retail price

share of wheat procurement price in the retail price of bread

Figure 6. Structure of wheat producers', milling, bakery and trade margins in the retail price of bread in Poland in 2004-2019 (\%).

Table 1 presents the values of correlation coefficients between all analyzed prices at each of the analyzed levels of final product price formation. Correlation values were calculated for monthly data on a scale of each year for which full data was available. It was assumed that strong relationships between the values under review occur in the case of correlation coefficients greater than $+/-0.7$. No correlation between the discussed values was assumed for the values in the range $+/-0.3$.

The strongest relationships were found between the average procurement prices of wheat and the selling prices of flour producers. In eleven years, there were observed very strong positive correlations between these values. In the following year, a weaker positive correlation occurred. And only in three years, according to the adopted assumptions, no correlation was found between these values. 
Table 1. Correlation coefficients between prices on individual links in the production and distribution chain of plain mixed bread in Poland in 2004-2018.

\begin{tabular}{ccccccc}
\hline Years & $\begin{array}{c}\text { Wheat } \\
\text { procurement } \\
\text { prices; flour } \\
\text { producer's } \\
\text { prices }\end{array}$ & $\begin{array}{c}\text { Wheat } \\
\text { procurement } \\
\text { prices; bread } \\
\text { producer's } \\
\text { prices }\end{array}$ & $\begin{array}{c}\text { Wheat } \\
\text { procurement } \\
\text { prices; retail } \\
\text { price of } \\
\text { bread }\end{array}$ & $\begin{array}{c}\text { Flour } \\
\text { producer's } \\
\text { prices; bread } \\
\text { producer's } \\
\text { prices }\end{array}$ & $\begin{array}{c}\text { Flour } \\
\text { producer's } \\
\text { prices; retail } \\
\text { prices of } \\
\text { bread }\end{array}$ & $\begin{array}{c}\text { Bread } \\
\text { producer's } \\
\text { prices; retail } \\
\text { prices of } \\
\text { bread }\end{array}$ \\
\hline 2004 & 0.91 & -0.63 & $\mathbf{0 . 1 5}$ & $\mathbf{- 0 . 8 0}$ & $\mathbf{- 0 . 0 1}$ & $\mathbf{0 . 0 7}$ \\
2005 & 0.85 & $\mathbf{- 0 . 0 8}$ & 0.86 & $\mathbf{0 . 2 5}$ & 0.79 & $\mathbf{- 0 . 2 1}$ \\
2006 & 0.93 & 0.95 & 0.94 & 0.94 & 0.94 & 1.00 \\
2007 & 1.00 & 0.90 & 0.90 & 0.89 & 0.89 & 1.00 \\
2008 & 0.94 & $\mathbf{- 0 . 8 5}$ & $\mathbf{- 0 . 9 2}$ & $\mathbf{- 0 . 7 1}$ & $\mathbf{- 0 . 8 0}$ & 0.98 \\
2009 & $\mathbf{0 . 1 1}$ & 0.43 & -0.54 & 0.43 & $\mathbf{- 0 . 1 4}$ & $\mathbf{- 0 . 0 7}$ \\
2010 & 0.97 & 0.89 & 0.88 & 0.91 & 0.89 & 0.99 \\
2011 & 0.90 & -0.35 & -0.37 & $\mathbf{- 0 . 2 7}$ & $\mathbf{- 0 . 3 0}$ & 0.98 \\
2012 & 0.94 & 0.89 & $\mathbf{0 . 1 6}$ & 0.94 & $\mathbf{0 . 0 2}$ & $\mathbf{0 . 0 6}$ \\
2013 & 0.95 & $\mathbf{0 . 2 8}$ & 0.91 & $\mathbf{0 . 1 5}$ & 0.96 & $\mathbf{0 . 0 7}$ \\
2014 & 0.81 & $\mathbf{0 . 2 8}$ & 0.43 & $\mathbf{0 . 2 6}$ & 0.54 & -0.32 \\
2015 & $\mathbf{0 . 2 1}$ & $\mathbf{- 0 . 1 4}$ & 0.49 & $\mathbf{- 0 . 7 6}$ & $\mathbf{0 . 1 3}$ & $\mathbf{- 0 . 2 5}$ \\
2016 & 0.60 & -0.59 & 0.46 & $\mathbf{- 0 . 8 4}$ & $\mathbf{0 . 2 5}$ & $\mathbf{- 0 . 0 9}$ \\
2017 & $\mathbf{- 0 . 2 5}$ & -0.50 & -0.40 & 0.75 & 0.67 & 0.97 \\
2018 & 0.91 & 0.92 & 0.92 & 0.98 & 0.98 & 1.00 \\
\hline
\end{tabular}

In the case of procurement prices of wheat and the prices of bread producers, significant positive correlations were found only in the five researched years. Similarly, strong relationships occurred in four of the analyzed years between all investigated price levels. These were the years 2006, 2007, 2010 and 2018. In the fifth of these years, strong relationships reached the level of bread producers. There was no correlation between 2008 and 2013-2015.

The procurement prices of wheat and the retail prices of bread were closely intertwined in six years. In 2005 and 2013, bread producers broke out of the chain of close links. In the remaining four years, these close relationships concerned all the links.

Bread producers and their sellers were strongly connected in terms of pricing in seven of the years analyzed. Apart from the years when price incentives were transmitted between all links in two years, in 2008 and 2011 there were strong connections only between procurement and flour producers and between bread producers and its sellers. In 2017, the prices at further stages were largely independent of wheat procurement prices. In price relations between bread producers and the trade, seven years were recorded when such relationships did not exist.

It should also be noted that the year 2008 was outstanding in terms of shaping mutual relations between prices at the analyzed levels. Close relationships occurred between the procurement prices of wheat and the prices of flour producers, and on the other hand between bread producers and retailers, but analyzing the remaining correlations, it can be concluded that there are high negative correlations. The prices at the first two levels fluctuated significantly while on the other two, they used to rise systematically.

\section{Conclusions}

In the years 2004-2019, the differences between the prices of cereal and flour production and the prices of secondary processing products systematically increased. At the first two levels, the prices fluctuated quite significantly and were often lower than at the beginning of the analyzed period. The producers and the sellers of bread, during periods of significant decreases in cereal procurement price 
and the producer's price for flour, usually kept their prices at a similar level, while periods of rising prices for cereals and flour were used for significant price increases.

The bakery margin had the largest share in the retail price of plain mixed bread in the entire reviewed period. The analyses show that in $88 \%$ of the examined months the share of bakery margin in the price of plain mixed bread was at least $50 \%$ and in nearly $53 \%$ of the total number of examined months its share was higher than $60 \%$. The variation of these shares was the lowest among the analyzed ones and amounted to $11.6 \%$. Bakery margins were, therefore, the highest and the most stable. This demonstrates the high consistency and freedom in price formation at this stage of bread production. The margins at the previous three stages were lower. It is also the answer to the question of how bread producers have been dealing with the problem of falling demand for their products that have been going on for many years.

The strongest relationships were found between the average procurement prices of wheat and the selling prices of flour producers. In eleven years, there were very strong positive correlations and only in three years, by the adopted assumptions, there were no correlations between these values. Bread producers and its sellers were strongly price-related in seven of the fifteen years analyzed. Only in four years (2006, 20072010 and 2018), there was a strong positive correlation between prices at all investigated stages. In two years (2008 and 2011) there were strong relationships only between procurement and flour producers as well as between bread producers and its sellers. In 2017, the prices at further stages were largely independent of wheat procurement prices. Analyzing the prices of bread producers and the prices in retail trade it was found up to seven years when they developed independently of each other.

Summing up the previous considerations, it can be said that the bread producers had a dominant position in the reviewed stages of bread production in the analyzed years. Their share in the final price was always the largest and most stable, and the price growth achieved by them was the highest.

\section{References}

Agricultural Market. Analyzes, Trends, Assessments. Monthly bulletins of IERiGŻ-PIB (2004-2019).

Cereal market Status and perspectives. Market surveys (2004-2019).

Firlej Krzysztof, Kowalska Anna., and Piwowar Arkadiusz. 2017. Competitiveness and innovation of the Polish food industry. Agricultural Economics: 63, 502-509, https://doi.org/10.17221/111/2016-AGRICECON.

Kettunen, Z. 1992. Price margins and trends in their formation. Zagadnienia Ekonomiki Rolnej, No. 5

Kowalska Anna Sylwia, Olszańska Anna, and Nabiałek Piotr. 2019. Production and external trade of dairy products in Poland. Paper presented at the Education Excellence and Innovation Management through Vision 2020 International Business Information Management Association Conference, Granada, Spain, April 10-11, pp. 4041-4050.

Kowalska Anna Sylwia, Tarnowska Agnieszka, and Kovárník Jaroslav. (2017). Polish - Czech Trade in Agri-Food Products Before and after Accession to the European Union. Paper presented at the International scientific conference Hradec Economic Days 2017, Hradec Králové, Czech Republic, January 31 - February 1, pp. 449-459. Available online: https://uni.uhk.cz/hed/site/assets/files/1046/proceedings_2017_1.pdf

Statistical yearbook of agriculture, Central Statistical Office, Warsaw, 2005-2019. 